\title{
The Fragile Axes of Life: A Capability Approach Perspective towards Graduates' Education-Job Mismatches and Subjective Well-Being
}

\author{
Petya Ilieva-Trichkova *(D) and Pepka Boyadjieva \\ Institute of Philosophy and Sociology, Bulgarian Academy of Science, 1000 Sofia, Bulgaria; pepka7@gmail.com \\ * Correspondence: petya.ilievat@gmail.com
}

\section{check for}

updates

Citation: Ilieva-Trichkova, Petya and Pepka Boyadjieva. 2021. The

Fragile Axes of Life: A Capability Approach Perspective towards

Graduates' Education-Job

Mismatches and Subjective Well-Being. Social Sciences 10: 262. https://doi.org/10.3390/socsci 10070262

\section{Academic Editor:}

Queralt Capsada-Munsech

Received: 17 May 2021

Accepted: 2 July 2021

Published: 8 July 2021

Publisher's Note: MDPI stays neutral with regard to jurisdictional claims in published maps and institutional affiliations.

Copyright: (c) 2021 by the authors. Licensee MDPI, Basel, Switzerland. This article is an open access article distributed under the terms and conditions of the Creative Commons Attribution (CC BY) license (https:/ / creativecommons.org/licenses/by/ $4.0 /)$.

\begin{abstract}
Using the capability approach as a theoretical framework, this article aims to: (1) explore how subjective individual well-being differs among higher education graduates and especially to what extent it is associated with graduates' vertical education-job mismatches; (2) reveal the embeddedness of the link between graduates' vertical education-job mismatches and subjective wellbeing in different socio-economic contexts; and (3) outline some policy implications of the analysis undertaken. It argues that vertical education-job mismatch among graduates has an important influence on experiences of the benefits that come from higher education. By analysing micro-level data from the European Social Survey, carried out in 2012 and macro-level data for 24 European countries via descriptive statistics and multilevel regression, the study shows that education-job mismatch is associated with capability deprivation, as graduates who are vertically mismatched have less interest in what they are doing, feel less autonomous and competent, and are less confident that they are leading a meaningful life or being treated with respect by others in comparison to those graduates who are employed in jobs which correspond to their level of education. The article also provides evidence that the association between graduates' education-job mismatches and individual subjective well-being is embedded in different socio-economic contexts.
\end{abstract}

Keywords: education-job mismatch; higher education; capability approach; subjective well-being; engagement; sense of meaning; competence; autonomy; recognition

\section{Introduction}

It is widely assumed that highly educated people are better integrated into the labour market and enjoy a higher quality of life due to their lower rates of unemployment compared to groups with lower levels of education. However, this assumption neglects the widespread tendency in recent years for graduates to be employed in jobs which very often do not require a tertiary degree. Thus, the over-qualification rate among graduates aged 25 to 34 in the European Union (EU) in 2019 was estimated at 24.1\%. Differences in that rate among countries are substantial, ranging from 9.7\% in Luxembourg to $15.2 \%$ in Denmark, $16.7 \%$ in Estonia, $17.3 \%$ in Sweden, $18.7 \%$ in Germany, and reaching $27.4 \%$ in Bulgaria, 28.7\% in Austria, 30.1\% in Slovakia, 38.8\% in Spain, and 48\% in Greece (European Centre for the Development of Vocational Training, Cedefop 2019).

The acceptance of jobs that are below one's level of education can be perceived as a means to overcome unemployment and find "shelter" from difficult social situations on the labour market. However, this strategy has its price, and, as a rule, it is at the expense of lower income, partial loss of human capital, and some negative subjective feelings.

This article is inspired by the understanding that "life is more than a set of commercial relations" (Nussbaum and Sen 1993, p. 9) and, because of that, any adequate assessment of individual and societal well-being requires taking into account different dimensions of life that are irreducible to one another. Using the capability approach as a general theoretical framework, it aims to: (1) explore how subjective individual well-being 
differs among higher education graduates and especially to what extent it is associated with graduates' vertical education-job mismatches; (2) reveal the embeddedness of the link between graduates' vertical education-job mismatches and subjective well-being in different socio-economic contexts; and (3) outline some policy implications of the analysis undertaken.

The article offers a critical, theoretically inspired, and empirically underpinned comparative analysis and argues that participation in higher education offers wider benefits than just economic ones and that the incidence of vertical education-job mismatch among graduates has an important influence on experiences of the benefits that come from higher education. It contributes to the literature in three main ways by: (1) applying the capability approach to studying the influence of graduates' vertical education-job mismatches on subjective well-being using data from a large-scale international survey, (2) adopting a more differentiated multi-dimensional understanding of subjective well-being that goes beyond its reduction to satisfaction and happiness, and (3) revealing that the effects of graduates' vertical education-job mismatches on subjective well-being are socially embedded. The analysis is based on data from the sixth wave of the European Social Survey, carried out in 2012 and country-level data for 24 European countries, and it has been carried out via descriptive statistics and multilevel regression modelling.

The article will proceed as follows. First, we will make a brief overview of previous studies. Then, we will discuss our theoretical conceptualisations on overeducation, focusing on the capability approach perspective towards education-job mismatch among tertiary graduates and their subjective well-being. After that, we will formulate our hypotheses. This will be followed by a description of the research methodology. Next, we will present the findings from the analysis. The final sections of the paper will offer a discussion of the results and some concluding remarks.

\section{Previous Literature}

There is a substantial body of literature on overeducation and skills mismatch. The research falls into three groups: (1) discussions of theoretical approaches and concepts, (2) research on the determinants of overeducation, and (3) studies on the consequences of overeducation. There are some reviews of this literature that summarise the concepts and methods of measurement used as well as provide international evidence on trends in overeducation, their determinants, and their consequences-especially in relation to earnings (e.g., McGuinness 2006; McGuinness et al. 2018; Delaney et al. 2020).

The results from the REFLEX (The flexible professional in the knowledge society new demands on higher education in Europe) project, carried out in 2006 and covering 15 European countries and Japan, demonstrate the existence of a huge difference in the proportions of graduates who are employed below their level of education across countries (Allen and van der Velden 2011). Using data from 30 EU countries, a recent study by Delaney et al. (2020) has shown that, while differences in overeducation between countries persist, and despite the rapid increase in tertiary educational attainment in the period 2000 to 2016, "the overeducation rates among young university graduate level employees decreased by a third over the same period, from approximately 60 percent in 2000 to around 40 percent in $2016^{\prime \prime}$ (p. 26).

Studies reveal that graduate employability is embedded within national and institutional contexts and that education-job mismatches can mirror structural problems in both the economy and the educational system. The level of vertical education-job mismatch among graduates differs significantly according to gender and year of graduation, but it is also influenced by educational degree and the institutional characteristics of higher education, such as the quality and orientation of higher education programmes (Verhaest and van der Velden 2013; Ilieva-Trichkova and Boyadjieva 2016, 2017).

According to the review by McGuinness et al. (2018), "one of the most studied aspects of overeducation is its effect on wages, and the evidence consistently points to a wage penalty for overeducated individuals, relative to individuals with the same education 
in matched employment", and "overeducated individuals earn $13.6 \%$ less than matched individuals" (p. 11). Using data for Dutch graduates, Allen and van der Velden (2001) show that educational mismatches have a strong effect on hourly wages. Chevalier and Lindley (2009)'s study, which relies on data for graduates from the United Kingdom, also finds evidence that the wage penalties for overeducation are significant. McGuinness and Sloane (2011) indicate that some overeducation may be voluntary, as workers may be willing to trade off earnings for other desirable job characteristics. The most studied subjective consequences of overeducation are job satisfaction and the level of happiness. However, the results are mixed. While some studies indicate that overeducation leads to lower job and life satisfaction (see, e.g., Verhaest and Omey 2006; Peiró et al. 2010; Diem 2015; Piper 2015; Congregado et al. 2016), others find that this is only the case when overeducation is also accompanied by overskilling (see, e.g., Green and Zhu 2010; Sloane and Mavromaras 2020). Mavromaras et al. (2012) and McGuinness and Byrne (2015) find that overeducation is only associated with lower job satisfaction for females. According to Fleming and Kler (2014), "this effect is particularly strong for females without children at home" (McGuinness et al. 2018, p. 12), and Frank and Hou (2017) reveal that the negative effect of overeducation is weaker among immigrant populations in comparison to non-immigrants. In a recent study, Voces and Caínzos (2020) concluded that the negative effects of overeducation are mostly confined to the sphere of work but are not evident in relation to overall subjective well-being.

Taking into account the previous literature, we think that there is a need for further research on the link between education-job mismatch and individual subjective wellbeing which applies a more sophisticated understanding of subjective well-being and pays attention to the embeddedness of education-job mismatch and its association with well-being in different socio-economic contexts. Limiting our analysis to higher education, we will try to answer the following research questions:

(1) How are graduates' education-job mismatches associated with different dimensions of individual subjective well-being?

(2) Does the relationship between graduates' education-job mismatches and different dimensions of individual subjective well-being differ in different socio-economic contexts?

\section{Theoretical Considerations}

\subsection{Graduates' Education-Job Mismatches and Capability Deprivation}

Støren and Arnesen (2011, p. 200) propose different forms of education-job mismatch: (1) unemployment, assumed to be the most severe form of mismatch; (2) vertical educational mismatch (usually defined as overeducation), which refers to a lack of correspondence between one's level of education acquired and the level required in a job; (3) horizontal educational mismatch, which captures working in a job matching one's own level but not field of education; and (4) horizontal and vertical educational mismatch, which refers to those both vertically and horizontally mismatched. We will focus only on vertical mismatch with regard to higher education.

McGuinness (2006) outlines that, although "[ $t$ ]here is no accepted unified theory of overeducation", "a significant portion of the literature on overeducation considers how the phenomenon sits within the context of existing views of the labour market, and quite a few studies have attempted to empirically test which theoretical perspective is most in keeping with the observed facts" (p. 389).

The mainstream view, which is grounded in human capital theory (HCT) (Schultz 1961; Mincer 1958; Becker [1964] 1993), emphasises the extent to which an individual can adapt to labour market demands and subsequently invest in improving their skills, knowledge, or other characteristics. The human capital perspective has exerted great influence on the rise of knowledge-economy discourse. It implies that education is a form of investment in individual human capital and that the increase of a person's stock in education, interpreted as a form of capital, may be perceived as a key to economic growth. The focus here is on the productive potential of human beings, and it is assumed that the 
individual makes decisions, is responsible for the reallocation of their resources in line with economic incentives - taking into account potential risks and uncertainties-and responds to the demand for skills. Within the human capital perspective, the level of human capital (acquired through formal education and/or non-formal training) is the main determinant of earnings. That is why, as McGuinness (2006) states, "overeducation, which is associated with worker under-utilization and wage rates below the marginal product, would appear entirely inconsistent with this view of the labour market" (pp. 389-90). However, he further emphasises that "[ $t$ ]he overeducation phenomenon does not necessarily overturn HCT as it is entirely plausible that workers will be overeducated in the short run, whilst firms adjust their production processes in order to fully utilize the individuals' human capital or alternatively for as long as it takes workers to find a more appropriate match through job search" (McGuinness 2006, p. 390).

In searching for alternative views to conceptualise overeducation, authors pay more attention to macro-structural elements and take into account the extent to which graduates' professional realisation is structured by inequalities and opportunity, affirming that it is not dependent on an individual's human capital alone. This line of reasoning is grounded in the job competition model (Thurow 1975) and positional theory (Hirsch 1976), developed by economists, but also in credentialist theory (Collins 1979) within sociology. More specifically, it regards graduates' position on the labour market as relational, contextual and, most importantly, conflictual (Tholen 2015). As Hirsch (1976) puts it: "[t]he value to me of my education depends not only on how much I have but also on how much the man ahead of me in the job line has" (p. 3). This reasoning implies a different view on overeducation and its explanation. In McGuinness's (2006) interpretation, “Thurow postulates that were an individual to observe his neighbor participating in education, then under the HCT framework that individual would be less likely to participate in education as supply would be higher and the return less. However, under the Job Competition Model, the same individual would now be more likely to participate as education is a defensive necessity, necessary to protect their place in the queue" (p. 392).

Although the job competition model offers a better understanding of the phenomenon of overeducation, this perspective relates it exclusively to the economic benefits that come from education. In search of another theoretical perspective that could provide a more comprehensive view on the roles of education and individuals' behaviour towards it, we will turn our attention to the capability approach.

The capability approach is associated mainly with the work of Nobel Prize-winning economist Amartya Sen and political philosopher Martha Nussbaum. It is a social justice normative theoretical framework for conceptualising and evaluating phenomena such as inequalities, poverty, and well-being. According to the capability approach, it is not so much the achieved outcomes (functionings) that matter but the real opportunities (capabilities) that one has for achieving those outcomes. More specifically, the concept of functionings reflects the various things that a person may value being or doing. Such things vary in complexity, from a very simple one such as being well-nourished to a more complex one such as being happy (Sen 1992). In contrast, a person's "capability" refers to the alternative combinations that are feasible for a person to achieve. As Sen (2009) puts it: "[ $t$ ]he idea of capability ... is oriented towards freedom and opportunities, that is the actual ability of people to choose to live different kinds of lives within their reach" (p. 235).

The capability approach goes beyond human capital theory by adopting a much richer vision of education and acknowledging both its intrinsic and instrumental value. According to Sen (1997), human capital theory looks at human beings mainly as the means of production, while they are also "the end of the exercise" (p. 1960). Sen emphasises that: "[t]he benefits of education thus exceed its role as human capital in commodity production. The broader human capability perspective would record-and value-these additional roles" (p. 1959). What is more, the instrumental role of education is narrowly perceived as limited only to economic productivity. In fact, investment in education could lead to other personal and social benefits as well and may be motivated by various reasons that are 
not only job-related. That is why "we must go beyond the notion of human capital, after acknowledging its relevance and reach. The broadening that is needed is additional and cumulative, rather than being an alternative to the 'human capital' perspective" (p. 1961).

The notion of capability implies a larger scope of benefits from education than improving economic production alone and includes influencing social change and enhancing the well-being and freedom of individuals and peoples. The human capability perspective focuses on the impact that education may have on expanding human ability to lead a valuable life and to make substantive choices (see Sen 1999, pp. 292-97). Drèze and Sen (2002) outline five different ways in which education can be valuable to the freedom of a person: intrinsic importance, instrumental personal roles, instrumental social roles, instrumental process roles, and empowerment and distributive roles. Robeyns (2006) developed a modified version of this typology and distinguished the following roles of education: intrinsic, instrumental economic personal, instrumental economic collective, instrumental non-economic personal, and instrumental non-economic collective. Taking these discussions into account, we have developed a normative model of the roles of higher education following two lines of reasoning: (1) level of influence-individual or societal; and (2) character of influence-intrinsic, instrumental, and transformative/empowering (Boyadjieva and Ilieva-Trichkova 2016). Our model clearly demonstrates the complex nature and plurality of the roles and values of higher education. At the individual level, we differentiate the roles of higher education related to different aspects of personality development, alongside graduates' employability, and classify them according to their instrumental, intrinsic, or transformative/empowering value. At the macro (societal) level, in addition to the widely acknowledged roles of higher education for economic and cultural development, we identify its role in the transmission and creation of new knowledge, the validation of different types of knowledge, and the legitimisation of important social values. We also take into account the empowerment role of higher education in terms of expanding the real freedoms that people enjoy and overcoming or reducing recognition inequalities.

This comprehensive view of the roles of higher education allows us to argue that individuals could have motives and expect benefits from higher education that go beyond purely economic and instrumental considerations. From this perspective, not only can we explain the massification of higher education, but we can also claim that the very term" overeducation" is not correct, as it reduces the complexity of benefits from higher education to the labour market. We further argue that when a person has a job that requires a lower level of education, this does not mean that $\mathrm{s} /$ he is overeducated because $\mathrm{s} / \mathrm{he}$ can use the acquired education in other social spheres. That is why, in order to account for education-job discrepancies, we will use the term" education-job mismatch" instead of" overeducation".

From the capability approach perspective, massive unemployment in affluent European societies, this most severe form of education-job mismatch, has several negative consequences for individuals that may not be well-reflected in the income distribution statistics.

As Sen (1999) puts it:

unemployment is not merely a deficiency of income that can be made up through transfers by the state (at heavy fiscal cost that can itself be a very serious burden); it is also a source of far-reaching debilitating effects on individual freedom, initiative and skills. Among the manifold effects, unemployment contributes to the "social exclusion" of some groups, and it leads to losses of self-reliance, self-confidence and psychological and physical health. (p. 21)

Sen further explains that these "far-reaching effects" of unemployment include "loss of work motivation, skill and self-confidence, increase in ailments and morbidity (and even mortality rates), disruption of family relations and social life, hardening of social exclusion and accentuation of racial tensions and gender asymmetries" (Sen 1999, p. 94). It is important to emphasise that this statement appears in a section of his book Development as Freedom titled "Unemployment and capability deprivation". Relying on this understand- 
ing of unemployment as a cause for capability deprivation which goes beyond income deficiency, as well as the above more general discussion of the capability approach, we define graduates' education-job mismatches as a lack of correspondence between level of acquired education and the level required for a job, which leads to capability deprivation with wider consequences for individual well-being than reduced economic benefits alone. This deprivation is related to both the opportunity and process aspects of freedom. The opportunity aspect of freedom refers to the ability of people to achieve what they value, no matter through which process that achievement comes about, while its second aspect attaches importance to the process of choice itself. The analysis below will take into account only the first aspect.

An emphasis on capabilities shifts the focus away from money-based measures, such as income or expenditure, onto the kind of life an individual can live. Nussbaum $(2000,2003,2011)$ suggests an open list $^{1}$ of 10 capabilities that are vital to the dignity of each human being and, because of that, she states that the following should be provided to all: (1) life; (2) bodily health; (3) bodily integrity; (4) the senses, imagination, and thought; (5) emotions; (6) practical reasoning; (7) affiliation; (8) relationships with other species; (9) play; and (10) control over one's environment. It is worth studying whether graduates education-job mismatches are associated with deprivation of any of these capabilities and thus with negative consequences for individual well-being.

\subsection{The Multi-Dimensional Character of Individual Subjective Well-Being and Capability Deprivation and Their Social Embeddedness}

Well-being is of central concern within the capability approach. According to Sen (1999), the understanding of well-being should focus on what people can be and can do, rather than simply on what they have. From such a perspective, both objective and subjective perceptions of well-being are indispensable. In his book Inequality Reexamined, Sen (1992) states that "[t]he well-being of a person can be seen in terms of quality (the 'well-ness', as it were) of the person's being" (p. 39). This conceptualisation emphasises the quality aspect of life which may cover the full spectrum of its dimensions-family, health, employment, education, leisure, etc. In Sen's (1992) view, well-being has two aspects: freedom and achievement. Whereas well-being freedom is "one's freedom to achieve those things that are constitutive of one's well-being" and "is best reflected by a person's capability set" (p. 57), well-being achievements focus on the concept of functionings. Robeyns (2017) emphasises that this distinction "is virtually absent from the wellbeing literature" (p. 119).

It is important to note that the capability approach engages with a more sophisticated understanding of subjective well-being which does not reduce it to happiness. Such an understanding may "imply a cognitive exercise by each person and an effort to take stock of and summarize the full range of elements that people value (e.g., their sense of purpose, the fulfilment of their goals and how they are perceived by others)" (Stiglitz et al. 2010, p. 65).

In one of his famous John Dewey lectures, Sen (1985) argues that:

happiness has two basic problems in its claim to stand for well-being. First, as it is interpreted in the utilitarian tradition, happiness is basically a mental state, and it ignores other aspects of person's well-being .... Second, as a mental-state concept, the perspective of happiness may give a very limited view of other mental activities ... such as stimulation, excitement, etc., which are of direct relevance to a person's well-being. Furthermore, mental activities involve valuation of one's life-a reflective exercise - and the role of valuation cannot be seen in terms merely of the happiness that such reflection itself creates. (pp. 188-89, emphasis in the original)

Sen (1985) concludes that "[i]t is hard to avoid the conclusion that although happiness is of obvious and direct relevance to well-being, it is inadequate as representation of well-being" (p. 189). 
The level of satisfaction also seems inadequate as a simple indicator of subjective well-being. Both Sen and Nussbaum use the concept "adaptive preferences" to show that people's desires may adjust to the circumstances in which they live and that such an internalisation of external constraints has an influence upon the individual's wellbeing. It may lead to paradoxical situations in which a poor and a rich person report the same levels of satisfaction. That is why, within the capability approach, the metrics of happiness and satisfaction are not viewed as a sufficient guide for the assessment of people's well-being. Sen and Nussbaum argue for the need to take into consideration some objective information (e.g., the real opportunities that people have). We claim that the multi-dimensional character of subjective well-being should also be taken into account. Sen, for example, mentions excitement and stimulation in addition to happiness. The authors of the module on personal and social well-being of the sixth round of the European Social Survey (European Social Survey 2013) suggest other dimensions of personal well-being and refer to resilience, meaning and purpose, autonomy, engagement, competence, and vitality. We think that another important dimension of subjective well-being is the sense of recognition. According to Charles Taylor (1992), receiving recognition is "is not just a courtesy but a vital human need" (p. 25). Recognition from others is crucial to each person's development and self-consciousness: through it, one comes to know their own specific characteristics and thus achieves one's identity. Due to that, "the experience of disrespect poses the risk of the injury that can cause the identity of the entire person to collapse" (Honneth 1992, p. 189).

On the basis of this discussion, in the present study, we will focus on the following dimensions of subjective well-being: engagement, competence, autonomy, sense of meaning, and recognition. All these dimensions touch upon some of the central human capabilities defined by Nussbaum (2003, pp. 41-42). More specifically:

- engagement is associated with emotions - "being able to have attachments to things" and to be interested in what you are doing.

- competence is associated with the senses, imagination, and thought-being able to "imagine, think and reason" ... "in a 'truly human' way, a way informed and cultivated by an adequate education, including, but by no means limited to, literacy and basic mathematical and scientific training".

- autonomy is associated with control over one's environment— "being able to participate effectively in political choices that govern one's life".

- $\quad$ sense of meaning is associated with practical reasoning - "being able to form a conception of the good and to engage in critical reflection about the planning of one's life".

- recognition - is associated with affiliation and control over one's environment—“' [b]eing able to live with and toward others" and to enter "into meaningful relationships of mutual recognition" with others.

Previous research shows how happiness as an indicator of individual subjective well-being is embedded and varies in different socio-economic and cultural contexts. For instance, Schyns (1998) provides evidence that there is a strong positive correlation between happiness and national economic and cultural living conditions. Deeming and Hayes (2012) found that respondents living in liberal and conservative countries experience at least twice the odds of unhappiness of those living in social democracies, after controlling for individual- and country-level explanatory variables. A recent paper demonstrates that while there is a positive correlation between participation in adult education and happiness, stronger variation exists according to the countries in which adults live (Boeren 2021). Thus, adult learners in Bulgaria are happier than those who are not, but these learners are still significantly less happy than those who do not participate in adult education in Finland.

On the basis of the above-outlined theoretical assumptions and the previous literature, we have formulated the following three hypotheses: 
Hypothesis 1 (H1). Graduates' vertical mismatch is negatively associated with the defined five dimensions of subjective individual well-being.

Hypothesis 2 (H2). Better economic and democratic development of a given country is positively associated with the defined five dimensions of the subjective individual well-being of graduates.

Hypothesis 3 (H3). There is an interaction effect between economic and democratic development and graduates' vertical mismatch, such that better economic and democratic development of a given country is negatively associated with subjective individual well-being among graduates who are employed below their level of education.

To sum up the reasoning: graduates' vertical education-job mismatches are associated with capability deprivation and thus with lowering individual subjective well-being in the above-described five dimensions. However, this association is embedded in the wider socio-economic contexts where graduates live. In the following section, we search for empirical evidence of this reasoning.

\section{Data, Measurements and Analytical Approach}

\subsection{Data}

The above-formulated hypotheses will be tested via data from the European Social Survey (ESS). We have used data from the ESS Round 6 (ESS Round 6: European Social Survey Round 6 Data 2012) because it has a rotating module specially devoted to personal and social well-being. The ESS is a biannual cross-national survey that is representative for the population aged 15 and over. This survey involves strict random probability sampling and a minimum target response rate of 70 percent. It is carried out via face-to-face interviews in more than 30 countries. We have used individual-level data from the ESS and combined them with macro-level data from the official statistics to explore, on the one hand, whether or not there are differences in the levels of subjective well-being among those higher education graduates who are vertically mismatched and, on the other, if institutional contexts moderate the associations between vertical mismatch and subjective individual well-being. The data are restricted to higher education graduates aged 25 to 64 years. Our sample consists of 24 countries for which there are data available on all country-level variable of interest. In order to obtain the same number of cases for each of the null and full models, categories for missing values in any of the individual-level independent and control variables were omitted from the analysis using listwise deletion. This resulted in a database of 9163 cases: Belgium $(n=445)$, Bulgaria $(n=380)$, Cyprus $(n=287)$; the Czech Republic $(n=207)$; Denmark $(n=513)$; Estonia $(n=487)$; Finland $(n=616)$; France $(n=421) ;$ Germany $(n=641) ;$ Great Britain $(n=418) ;$ Hungary $(n=261)$; Iceland $(n=206)$; Ireland $(n=580) ;$ Italy $(n=124)$; Lithuania $(n=495) ;$ the Netherlands $(n=457)$; Norway $(n=524) ;$ Poland $(n=306) ;$ Portugal $(n=167) ;$ Slovakia $(n=231)$; Slovenia $(n=221)$; Spain $(n=356)$; Sweden $(n=455)$; and Switzerland $(n=365)$. Still, due to missing observations in the dependent variables, the number of analytical samples slightly differs across models. This is why the number of individuals in each model is provided below.

The data at a country level were extracted from the Eurostat website and a report from The Economist Intelligence Unit (2012). These data are current for 2012.

\subsection{Measurements}

It is important to underline that one of the features of capability is that it is not directly measurable. As such, most scholars evaluate outcomes (functionings) and draw conclusions about the capability of people. Although Sen gives priority to capabilities instead of functionings as an evaluative space of well-being, he stresses that there is no difference between focusing on functioning or capability. This problem with measuring capabilities has been noted by Robeyns (2003), who points out: "given that we have 
little direct information about people's capability levels, we could start by taking group inequality in achieved functionings as indicative of inequalities in capabilities" (p. 85).

In line with Suppa (2015), our empirical strategy involved subjective indicators for detecting capability deprivation. We have focused on revealing whether graduates' vertical mismatches are associated with capability deprivation and thus with lowering individual subjective well-being in the five dimensions described above. More concretely, we have used the following five dependent variables.

1. To measure engagement, we relied on the following question in the ESS: D32 How much of the time would you generally say you are absorbed in what you are doing? The answer scale had 11 options ranging from 0 , none of the time, to 10 , all of the time. This variable was dichotomised into two categories: $1=$ feeling absorbed most of the time, which includes scores 7 to 10 , and $0=$ otherwise.

2. To measure competence, we used the following statement in the ESS: D17 In my daily life, I get very little chance to show how capable I am. The respondents were offered five options to answer: 1 = agree strongly, 2 = agree, 3 = neither agree nor disagree, $4=$ disagree, and $5=$ disagree strongly. Their answers were entered into the analysis as a dummy variable: 1 = having a high chance to show how capable I am, covering options 4 and 5 , and $0=$ otherwise.

3. To measure autonomy, we relied on the following statement in the ESS: D16 I feel I am free to decide for myself how to live my life. The respondents were offered five options to answer: 1 = agree strongly, 2 = agree, $3=$ neither agree nor disagree, $4=$ disagree, and $5=$ disagree strongly. This item was entered into the analysis as a dummy variable having two values: 1 = feeling free to decide how to live my life, which included answers 1 and 2 , and $0=$ otherwise.

4. To measure the sense of meaning, we used the following statement in the ESS: D23 I generally feel that what I do in my life is valuable and worthwhile. The respondents were offered five options to answer: $1=$ agree strongly, $2=$ agree, $3=$ neither agree nor disagree, $4=$ disagree, and $5=$ disagree strongly. This item was entered into the analysis as a dummy variable having two values: $1=$ feeling that what I do in life is valuable and worthwhile, covering options 1 and 2 , and $0=$ otherwise.

5. To measure recognition, we used the following question in the ESS: D22 To what extent ... do you feel that people treat you with respect? The respondents were provided with a seven-point Likert scale, ranging from 0 , not at all, to 6 , a great deal. This variable was recoded and entered into the analysis as a dummy variable having two values: $1=$ feeling that people treat me with respect, including responses 4 to 6 , and $0=$ otherwise.

The main independent variable included at the individual level was the dummy variable of being vertically mismatched ( $1=$ yes). As stated above, it "refers to the lack of correspondence between the level of the education acquired and the level required in the job" (Støren and Arnesen 2011, p. 200).

Indeed, there is no uniform, undisputable typology or measurement framework regarding education-job mismatch (see Quintini 2011; ILO 2014). In this article, we have used a normative approach for its assessment. The reason for that is twofold. On the one hand, we wanted to use as many objective measures as possible. On the other hand, this approach was preferred in some recent reports (e.g., European Commission 2012). Thus, vertical (education-job) mismatch was measured as the percentage of graduates whose occupation is not in the first three categories of the International Standard Classification of Occupations (ISCO 08). More specifically, ISCO 1, 2, and 3 are categories of occupations usually requiring tertiary qualifications. ISCO 1 refers to managers and ISCO 2 refers to professionals, whereas ISCO 3 refers to technicians and associate professionals. Therefore, higher education graduates who are employed in some of the other categories, ISCO 4-9, are classified as vertically mismatched.

In order to reveal if the relationship between graduates' education-job mismatches and different dimensions of individual subjective well-being varies in different socio-economic 
contexts, we have included interaction terms between being vertically mismatched and two macro level variables which capture the most important characteristics of a given social environment-economic and democratic development:

1. GDP per capita in PPS (volume indices of real expenditure per capita (in PPS_EU27_2020 $=100$, Eurostat, Data code TEC00114, extracted on 8 April 2021). The highest GDP is in Norway at 188, and the lowest is in Bulgaria at 47.

2. Democracy regime. The report from The Economist Intelligence Unit (2012) developed a democracy index that ranges from 0 to 10 and is composed of 60 indicators grouped into five categories: electoral process and pluralism; civil liberties; functioning of government; political participation; and political culture. The index values are used to place countries within four types of regimes: 8-10 means full democracy, 6-7.9 means flawed democracy, 4-5.9 means hybrid democracy, and $<4$ means authoritarian regime. Among the 24 countries studied, the highest score on the democracy index is in Norway at 9.93 and the lowest is in Bulgaria at 6.72. Thus, all 24 countries fall into the first two categories. Among them, the following countries are defined as full democracies: Belgium, the Czech Republic, Denmark, Finland, Germany, Great Britain, Iceland, Ireland, the Netherlands, Norway, Spain, Sweden, and Switzerland. The rest of the countries are defined as flawed democracies: Bulgaria, Cyprus, Estonia, France, Hungary, Italy, Lithuania, Poland, Portugal, Slovakia, and Slovenia. This information was entered into the analysis as a dummy variable ( $1=$ full democracy).

We have further included six individual-level control variables for age (continuous) and the following dummy variables: gender $(1=$ female; $0=$ male); parents' education as an indicator of social background ( 1 = high (including persons with at least one parent with higher education), 0 = low (including persons without a parent with higher education)); belonging to a minority ethnic background $(1=$ yes, $0=$ no); living with a husband/wife/partner $(1=$ yes; $0=$ no); and participation in work-related training in the previous 12 months $(1=$ yes; $0=$ no).

We have used the unweighted data from the ESS in all statistical analyses. Descriptive statistics of all dependent, independent, and control variables used in the empirical analysis are presented in Table A1 in Appendix A.

\subsection{Analytical Approach}

As a first step, we assessed whether there are differences in the mean values on the different dimensions of subjective well-being among graduates who are vertically mismatched and those who are not via the use of an independent $t$-test. In this test, we used the answer scales before the dichotomisation and transformed them where necessary to assign a positive value to the highest category.

As a second step, we applied multilevel modelling in the analyses. These models are especially useful in handling nested data (see Rabe-Hesketh and Skrondal 2012) and have allowed us to explore the influence of vertical mismatch as well as macro-level factors on different aspects of subjective individual well-being. More specifically, we applied random effects logit models. In contrast to fixed effects models, we were able to include variables at level 2 by using random effects models. Furthermore, these models were chosen as appropriate because they allow for the estimation of cross-level interaction terms.

More specifically, for each of the five dependent variables, we used an empty (unconditional) model, where we examined the extent of variance in the outcome variables attributed to the country level. We then estimated three separate models for each dependent variable. In the first models, we included the variable of being vertically mismatched. In the second models, we also included an interaction term between being vertically mismatched and country-level GDP per capita. In the third models, we included an interaction term between being vertically mismatched and the country's democracy regime. These models were estimated using the xtlogit command in Stata 16. 


\section{Results}

We have found that there are statistically significant mean differences between those graduates who are vertically mismatched or not in agreement with the statements listed in Table 1 . This shows that graduates who are vertically mismatched have less interest in what they are doing, feel less autonomous and competent, and are less confident that they are leading a meaningful life or being treated with respect by others in comparison to those graduates who are employed in jobs which correspond to their level of education.

Table 1. Statements regarding the five dimensions of subjective well-being among graduates for which a significant difference was detected between those who are mismatched and not.

\begin{tabular}{|c|c|c|c|c|c|c|c|}
\hline $\begin{array}{c}\text { Dimensions of } \\
\text { Subjective Well-Being }\end{array}$ & Statement & $\begin{array}{c}\text { Vertically } \\
\text { Mismatched }\end{array}$ & Mean & St. Dev. & $t$ & df & $p$ \\
\hline \multirow{2}{*}{ Engagement } & \multirow{2}{*}{$\begin{array}{l}\text { Feeling absorbed in what } \\
\text { you are doing }\end{array}$} & No & 7.71 & 1.65 & \multirow[t]{2}{*}{5.64} & \multirow[t]{2}{*}{9130} & \multirow[t]{2}{*}{0.00} \\
\hline & & Yes & 7.47 & 1.80 & & & \\
\hline \multirow{2}{*}{ Competence } & \multirow{2}{*}{$\begin{array}{l}\text { Having a high chance to } \\
\text { show how capable I am }\end{array}$} & No & 3.62 & 1.02 & \multirow[t]{2}{*}{13.97} & \multirow[t]{2}{*}{9142} & \multirow[t]{2}{*}{0.00} \\
\hline & & Yes & 3.26 & 1.08 & & & \\
\hline \multirow{2}{*}{ Autonomy } & \multirow{2}{*}{$\begin{array}{l}\text { Feeling free to decide how } \\
\text { to live my life }\end{array}$} & No & 4.10 & 0.83 & \multirow[t]{2}{*}{4.40} & \multirow[t]{2}{*}{9156} & \multirow[t]{2}{*}{0.00} \\
\hline & & Yes & 4.01 & 0.88 & & & \\
\hline \multirow{2}{*}{ Sense of meaning } & \multirow{2}{*}{$\begin{array}{l}\text { Feeling that what I do in life } \\
\text { is valuable and worthwhile }\end{array}$} & No & 4.15 & 0.67 & \multirow{2}{*}{8.42} & \multirow{2}{*}{9147} & \multirow[t]{2}{*}{0.00} \\
\hline & & Yes & 4.00 & 0.71 & & & \\
\hline \multirow{2}{*}{ Recognition } & \multirow{2}{*}{$\begin{array}{c}\text { Feeling that people treat } \\
\text { you with respect }\end{array}$} & No & 4.68 & 0.96 & \multirow[t]{2}{*}{5.71} & \multirow[t]{2}{*}{9103} & \multirow[t]{2}{*}{0.00} \\
\hline & & Yes & 4.53 & 1.09 & & & \\
\hline
\end{tabular}

Table 2 presents the baseline (null) regression models for all five selected dependent variables. The unconditional intraclass correlation (ICC) in these models ranges from 0.023 for "feeling that what I do in life is valuable and worthwhile" to 0.129 for "feeling absorbed in what you are doing most of the time". This shows that between $2.3 \%$ and $12.9 \%$ of the variation in variables which reflect different aspects of subjective individual wellbeing is due to differences between the countries where higher education graduates live.

Table 2. Null models.

\begin{tabular}{cccccc}
\hline Random Parameters & Engagement & Competence & Autonomy & $\begin{array}{c}\text { Sense of } \\
\text { Meaning }\end{array}$ & Recognition \\
\hline Intraclass correlation & 0.129 & 0.107 & 0.048 & 0.023 & 0.122 \\
Country-level variance & $0.487^{*}$ & $0.393 * *$ & $0.165^{* *}$ & $0.079^{* *}$ & $0.457^{*}$ \\
\hline BIC & 8556.1 & $11,386.3$ & 8243.2 & 6413.9 & 6300.5 \\
Observations & 9132 & 9144 & 9158 & 9149 & 9105 \\
\hline
\end{tabular}

Source: European Social Survey 2012, own calculations. Significance: ${ }^{*} p<0.05,{ }^{* *} p<0.01$. Abbreviations: Engagement $=$ feeling absorbed in what I am doing most of the time; competence $=$ having a high chance to show how capable I am; autonomy = feeling free to decide how to live my life; sense of meaning = feeling that what I do in life is valuable and worthwhile; recognition = feeling that people treat me with respect. BIC $=$ Bayesian information criterion.

The models in Tables 3 and 4 test if there are cross-level interactions between being vertically mismatched and GDP per capita and democracy regime regarding the measurement of all studied aspects of well-being. The cross-level interactions represent the difference in the effect of these two macro-level variables between graduates who are vertically mismatched and those who are employed in education-matched jobs. Although we have included a set of control variables in the models, we have not discussed them but rather here focus on the associations between vertical mismatch and cross-level interactions. 
Table 3. Influence of vertical mismatch on different aspects of subjective well-being and cross-level interactions between vertical mismatch and GDP per capita in PPS, odds ratios (standard errors in parentheses).

\begin{tabular}{cccccc}
\hline $\begin{array}{c}\text { Fixed Parameters } \\
\text { Engagement }\end{array}$ & Competence & Autonomy & $\begin{array}{c}\text { Sense of } \\
\text { Meaning }\end{array}$ & Recognition \\
\hline $\begin{array}{c}\text { Vertically mismatched vs. } \\
\text { not }\end{array}$ & $\begin{array}{c}0.505^{* *} \\
(0.108)\end{array}$ & $\begin{array}{c}0.874 \\
(0.170)\end{array}$ & $\begin{array}{c}0.674+ \\
(0.159)\end{array}$ & $\begin{array}{c}0.429^{* *} \\
(0.110)\end{array}$ & $\begin{array}{c}1.304 \\
(0.353)\end{array}$ \\
\hline GDP per capita in PPS & 0.997 & $1.013^{* *}$ & $1.008^{* *}$ & $1.004^{* *}$ & $1.015^{* *}$ \\
& $(0.004)$ & $(0.003)$ & $(0.002)$ & $(0.001)$ & $(0.003)$ \\
\hline GDP per capita in PPS X & $1.004^{*}$ & $0.996^{*}$ & 1.002 & 1.004 & $0.995^{*}$ \\
vertically mismatched & $(0.002)$ & $(0.002)$ & $(0.002)$ & $(0.002)$ & $(0.003)$ \\
\hline Constant & $4.795^{* *}$ & $0.336^{* *}$ & $3.816^{* *}$ & $3.640^{* *}$ & 1.212 \\
\hline Random parameters & $(2.355)$ & $(0.108)$ & $(1.014)$ & $(0.753)$ & $(0.450)$ \\
\hline Intercept & & & & $0.095^{* *}$ & $0.458^{* *}$ \\
Country-level variance & $0.686^{*}$ & $0.432 * *$ & $0.304 * *$ & $0.009 *$ & $0.209 * *$ \\
\hline Intraclass correlation & 0.125 & $0.187^{* *}$ & $0.093 * *$ & 0.003 & 0.060 \\
BIC & 8560.2 & $11,187.9$ & 8265.8 & 6293.5 & 6305.7 \\
\hline (individuals) & 9132 & 9144 & 9158 & 9149 & 9105 \\
\hline
\end{tabular}

Source: European Social Survey 2012, own calculations. Notes: All models are controlled for age, gender, parents education, ethnic background, marital status, and participation in work-related training in the previous 12 months $n$ (countries) $=24$. Significance: $+p<0.10,{ }^{*} p<0.05,{ }^{* *} p<0.01$. Abbreviations: Engagement $=$ feeling absorbed in what I am doing most of the time; competence = having a high chance to show how capable I am; autonomy = feeling free to decide how to live my life; sense of meaning $=$ feeling that what I do in life is valuable and worthwhile; recognition = feeling that people treat me with respect; GDP per capita in PPS = Gross domestic product (GDP) in Purchasing Power Standards (PPS); BIC = Bayesian information criterion.

Table 4. Influence of vertical mismatch on different aspects of subjective well-being and cross-level interactions between vertical mismatch and democracy regime, odds ratios (standard errors in parentheses).

\begin{tabular}{|c|c|c|c|c|c|}
\hline Fixed Parameters & Engagement & Competence & Autonomy & $\begin{array}{l}\text { Sense of } \\
\text { Meaning }\end{array}$ & Recognition \\
\hline $\begin{array}{l}\text { Vertically mismatched vs. } \\
\text { not }\end{array}$ & $\begin{array}{l}0.789 * \\
(0.081)\end{array}$ & $\begin{array}{l}0.676^{* *} \\
(0.059)\end{array}$ & $\begin{array}{l}0.842+ \\
(0.086)\end{array}$ & $\begin{array}{l}0.604 * * \\
(0.070)\end{array}$ & $\begin{array}{c}1.013 \\
(0.117)\end{array}$ \\
\hline $\begin{array}{l}\text { Full democracy vs. } \\
\text { flawed democracy }\end{array}$ & $\begin{array}{l}1.095 \\
(0.321)\end{array}$ & $\begin{array}{l}2.190 * * \\
(0.434)\end{array}$ & $\begin{array}{l}1.520 * * \\
(0.242)\end{array}$ & $\begin{array}{l}1.195 \\
(0.141)\end{array}$ & $\begin{array}{l}2.180 * * \\
(0.551)\end{array}$ \\
\hline $\begin{array}{c}\text { Full democracy X } \\
\text { vertically mismatched }\end{array}$ & $\begin{array}{c}0.982 \\
(0.129)\end{array}$ & $\begin{array}{l}0.778 * \\
(0.087)\end{array}$ & $\begin{array}{c}1.010 \\
(0.136)\end{array}$ & $\begin{array}{c}1.069 \\
(0.161)\end{array}$ & $\begin{array}{l}0.602 * * \\
(0.093)\end{array}$ \\
\hline Constant & $\begin{array}{l}3.215^{* *} \\
(0.807)\end{array}$ & $\begin{array}{c}0.839 \\
(0.152)\end{array}$ & $\begin{array}{l}6.763 * * \\
(1.207)\end{array}$ & $\begin{array}{l}5.153 * * \\
(0.908)\end{array}$ & $\begin{array}{l}3.906^{* *} \\
(0.939)\end{array}$ \\
\hline \multicolumn{6}{|l|}{ Random parameters } \\
\hline Intercept & $0.694 *$ & $0.463 * *$ & $0.351 * *$ & $0.198 * *$ & $0.576^{* *}$ \\
\hline Country-level variance & 0.481 * & $0.215^{* *}$ & $0.123 * *$ & $0.039 * *$ & $0.332 * *$ \\
\hline Intraclass correlation & 0.128 & 0.061 & 0.036 & 0.012 & 0.092 \\
\hline BIC & 8564.9 & $11,191.0$ & 8272.0 & 6304.3 & 6307.6 \\
\hline$n$ (individuals) & 9132 & 9144 & 9158 & 9149 & 9105 \\
\hline
\end{tabular}

Source: European Social Survey 2012, own calculations. Notes: All models are controlled for age, gender, parents education, ethnic background, marital status, and participation in work-related training in the previous 12 months; $n$ (countries) $=24$. Significance: $+p<0.10, * p<0.05,{ }^{* *} p<0.01$. Abbreviations: Engagement $=$ feeling absorbed in what I am doing most of the time; competence = having a high chance to show how capable I am; autonomy $=$ feeling free to decide how to live my life; sense of meaning $=$ feeling that what I do in life is valuable and worthwhile; recognition $=$ feeling that people treat me with respect. $\mathrm{BIC}=$ Bayesian information criterion.

The models' estimates in Table 3 show that the negative associations between being vertically mismatched and the studied five measures of subjective individual well-being remain significant for four of these measures, even after the inclusion of an interaction term between GDP and being vertically mismatched. They also reveal that high levels of GDP per capita are associated with higher levels of all measures of subjective well-being studied, 
except for "feeling absorbed in what you are doing most of the time", where this association is not significant. We have also found that once an interaction term between GDP per capita and being vertically mismatched is added to the models, the associations between being vertically mismatched and two out of five measures of subjective individual well-being ("having a high chance to show how capable I am" and "feeling that people treat you with respect") become insignificant. At the same time, this effect reaches a negative interaction of terms between being vertically mismatched and GDP per capita. This means that higher values of GDP per capita are significantly associated with lower odds of graduates stating they have a high chance to show how capable they are or to feel that people treat them with respect among those who are vertically mismatched. Our analysis also shows that there is a positive interaction term between GDP per capita and being vertically mismatched regarding measurement of the engagement aspect of well-being. This means that vertically mismatched graduates who live in more economically developed countries are more likely to be absorbed in what they are doing most of the time in comparison to their peers who have education-matched jobs.

The models' estimates in Table 4 reveal that the negative associations between being vertically mismatched and the studied five measures of subjective individual well-being remain significant for four of these measures, even after the inclusion of an interaction term between the democracy regime and being vertically mismatched. They also show that graduates living in countries with full democracies are more likely to have a high chance to show how capable they are, to feel free to decide how to live their life, and to feel that people treat them with respect compared to graduates living in countries with flawed democracies. Our analyses have found two negative cross-level interaction terms between democracy regime and being vertically mismatched. More specifically, we have found evidence that living in a full democracy is associated with lower odds of graduates having a high chance to show how capable they are among those who are employed in jobs which do not correspond to their level of education. The results also show that vertically mismatched graduates who live in fully democratic countries are less likely to feel that people treat them with respect in comparison to their peers who have education-matched jobs.

\section{Discussion}

This article presents a theoretically inspired and empirically grounded analysis of vertical education-job mismatch among higher education graduates and its association with their experience of the benefits that come from higher education as well as their own subjective well-being. On the basis of the discussion about the main concepts and potential of the capability approach, it provides solid evidence for the relevance and usefulness of this approach in understanding the phenomenon of graduates' education-job mismatches and its wider consequences beyond economic ones.

Albeit making undoubtedly valuable contributions, studies on graduates' professional realisation which use the capability approach are predominantly based on small-scale surveys or have focused on the problem within one country (e.g., Bergström 2012; Hinchliffe 2013; Walker and Fongwa 2017). The present article demonstrates that this approach can be a guiding theoretical framework in analyses which use large-scale studies and cover more than one country.

Relying on the capability approach, we reconsider three important concepts. First, we claim that the term "overeducation" is not adequate to capture the relationship between education and its benefits for individuals because it reduces the complexity of these benefits to purely economic ones, overlooking the fact that a person can use their acquired education in other social spheres than just the labour market. That is why we have applied the term "education-job mismatch" instead of "overeducation". Second, we define graduates' education-job mismatches as leading to capability deprivation with wider consequences than reduced economic benefits, including effects on different capabilities related to individual subjective well-being. Third, we present a multi-dimensional understanding of subjective well-being which goes beyond its reduction to happiness and satisfaction. 
Our understanding that subjective well-being is a multi-dimensional phenomenon is in line with Stiglitz et al. (2010)'s thesis that "the subjective dimensions of quality of life encompass several aspects" (p. 65). However, focusing on subjective well-being from the capability approach perspective, we do acknowledge that the capability approach also emphasises that "subjective states are not the only things that matter, and that expanding people's opportunities is important in itself, even if this does not show up in greater subjective well-being" (p. 64). Combining both objective and subjective measures of wellbeing is very important because of the "adaptive preferences" already mentioned. As Robeyns (2017, p. 137) explains:

[t]wo persons who find themselves in the same objective situation will have a very different subjective assessment, because one is happy with small amounts of 'objective goods', whereas the other is much more demanding. In the capability literature, the general concern is with deprived persons who, over time, adapt to their objectively poor circumstances, and report a level of subjective wellbeing which is higher than the objective circumstances warrant.

The results obtained clearly show that graduates who experience one of the mostwidely spread education-job mismatches-the mismatch between their level of education and the job they have (so-called vertical mismatch) - have less interest in what they are doing, feel less autonomous and competent, and are less confident in having a meaningful life or being treated with respect by others in comparison to those graduates who are employed in jobs which correspond to their level of education. These findings confirm our first hypothesis and demonstrate that graduates' education-job mismatch is associated with capability deprivation, as it has negative consequences on important dimensions of individual subjective well-being.

Our analysis further reveals that the association between graduates' education-job mismatches and individual subjective well-being is embedded in different socio-economic contexts. According to the findings, high levels of GDP per capita are associated with higher response levels in four of the dimensions of subjective well-being studied; among those living in a country with full democracies-in three dimensions. This means that societies with high levels of economic and democratic development provide a more favourable environment for subjective well-being among all individuals. These results are in line with our second hypothesis.

Special attention should be given to our findings that vertically mismatched graduates who live in more economically developed countries are less likely to show how capable they are or to feel that people treat them with respect and are more likely to be absorbed in what they are doing in comparison to their peers who have education-matched jobs. Regarding democracy, our results suggest that full democracy is less favourable to the subjective well-being of vertically mismatched graduates because they are less likely to show how capable they are or to feel that people treat them with respect in comparison to their peers in countries with full democracy who have education-matched jobs. These results probably demonstrate that competence is highly valued and recognition is given for high achievements in economically and democratically developed countries, and that is why education-jobs mismatches are viewed as capability deprivation. To a great extent, they confirm our third hypothesis but also demonstrate that subjective well-being is a complex phenomenon; each of its dimensions has specificity deserving special attention.

\section{Conclusions}

The article draws attention to the association between subjective individual well-being with graduates' vertical education-job mismatches and the embeddedness of this link in different socio-economic contexts. Having in mind the global trend towards the expansion of higher education (Schofer and Meyer 2005), we can expect that education-job mismatches will continue to be a possible characteristic of graduates' professional realisation. That is why this phenomenon, its effects on graduates' objective and subjective well-being, and 
its role in developing higher education policies all deserve constant attention from both scholars and policymakers.

Our study has some limitations. They mainly reflect the specificity of the data used. Aspects of subjective well-being other than happiness and job satisfaction were included only in the ESS 2012. As a result, it was not possible to reveal any trends over time. Another limitation related to the available data is that we used only one indicator for each of the dimensions of subjective well-being. Furthermore, as the ESS is a cross-sectional survey and does not collect longitudinal data, this did not allow us to study how the incidence of being vertically mismatched changes in later life stages.

We envisage several directions for future research. The first direction is related to further developing the conceptualisation of: (a) the multi-dimensional character of subjective well-being and its measurement, including measuring each variable with more than one item; and (b) understanding graduates' education-job mismatches through associations with capability deprivation, e.g., by also taking into account the process aspect of freedom. Secondly, the embeddedness of the association between graduates' vertical education-job mismatches and subjective well-being is worth studying while taking into account other macro characteristics, for example, the level of social inequality or the dominant cultural norms in a society (e.g., individualism vs. collectivism). Thirdly, special attention needs to be paid to the mechanisms through which social environments mediate the association between graduates' vertical education-job mismatches and subjective wellbeing. Fourthly, it is very important to note that the capability deprivation caused by graduates' education-job mismatches is linked to inequalities. As Sen (1992) states, this "applies particularly to the differentiation of class, community, caste, and gender" (p. 55). Last but not least, in line with previous research which shows that that education-job mismatch can be measured by different indicators (e.g., Verhaest and Omey 2006; CapsadaMunsech 2019), it would be worthwhile to test our results with other measures of graduates' education-job mismatches by using both quantitative and qualitative data and especially comparative longitudinal data.

The theoretical analysis and results obtained also have some policy implications. They clearly demonstrate that higher education policy should be based on an understanding of the complex nature and plurality of the roles and values of higher education. Acknowledgement of the crucial role of higher education for individuals' employability and economic benefits must be given alongside that of the intrinsic and transformative role of higher education at both individual and societal levels, both upon entry and in the process of higher education, including its role in subjective well-being.

Under conditions of massification and diversification, higher education increasingly functions as a positional good because a growing number of people graduate from higher education institutions, and this intensifies mutual competition between them. This points to the need for active intervention and compensation policies, to be placed simultaneously and in conjunction with both higher education and the labour market. It is beyond doubt that national higher education systems are embedded in different socio-economic contexts. That is why the effectiveness of higher education policies strongly depends on their relevance to the characteristics and needs of societies and labour markets, on the one hand, and students and graduates of higher education, on the other.

Author Contributions: Author Contributions: Conceptualization, P.B. and P.I.-T.; Formal analysis, P.I.-T.; Investigation, P.B.; Methodology, P.B. and P.I.-T.; Project administration, P.B.; Resources, P.B.; Software, P.I.-T.; Supervision, P.B.; Validation, P.I.-T.; Visualization, P.I.-T.; Writing-original draft, P.B.; Writing-review and editing, P.B. and P.I.-T. Both authors have read and agreed to the published version of the manuscript.

Funding: This research was funded by the Bulgarian National Science Fund, contract number KП06-ДВ-2/16.12.2019 within the project "Dynamics of inequalities in participation in higher and adult education: A comparative social justice perspective", the National Science Program VIHREN.

Institutional Review Board Statement: Not applicable. 
Informed Consent Statement: Not applicable.

Data Availability Statement: Not applicable.

Acknowledgments: We would like to thank the three anonymous reviewers for their valuable comments on an earlier version of this article.

Conflicts of Interest: The authors declare no conflict of interest.

\section{Appendix A}

Table A1. Descriptive statistics of all variables analysed after listwise deletion of individual-level independent and control variables.

\begin{tabular}{|c|c|c|c|}
\hline Variables & Value (No/Yes) & Percentage & Frequency \\
\hline \multicolumn{4}{|c|}{ Dependent variables } \\
\hline \multirow{2}{*}{$\begin{array}{l}\text { Engagement: feeling absorbed in what you } \\
\text { are doing }\end{array}$} & No & 20.19 & 1844 \\
\hline & Yes & 79.81 & 7244 \\
\hline \multirow{2}{*}{$\begin{array}{l}\text { Competence: having a high chance to show } \\
\text { how capable I am }\end{array}$} & No & 36.92 & 3376 \\
\hline & Yes & 63.08 & 5768 \\
\hline \multirow{2}{*}{$\begin{array}{l}\text { Autonomy: feeling free to decide how to } \\
\text { live my life }\end{array}$} & No & 17.08 & 1564 \\
\hline & Yes & 82.92 & 7594 \\
\hline \multirow{2}{*}{$\begin{array}{l}\text { Sense of meaning: feeling that what I do in } \\
\text { life is valuable and worthwhile }\end{array}$} & No & 11.23 & 1027 \\
\hline & Yes & 88.77 & 8122 \\
\hline \multirow{2}{*}{$\begin{array}{c}\text { Recognition: feeling that people treat you } \\
\text { with respect }\end{array}$} & No & 11.62 & 1058 \\
\hline & Yes & 88.38 & 8047 \\
\hline \multicolumn{4}{|c|}{ Independent variables at individual level } \\
\hline \multirow{2}{*}{ Being vertically mismatched } & No & 78.06 & 7153 \\
\hline & Yes & 21.94 & 2010 \\
\hline \multicolumn{4}{|c|}{ Control variables at individual level } \\
\hline Age & $43.48 *$ & & \\
\hline \multirow{2}{*}{ Female } & No & 43.45 & 3981 \\
\hline & Yes & 56.55 & 5182 \\
\hline \multirow{2}{*}{ High parents' education } & No & 60.03 & 5501 \\
\hline & Yes & 39.97 & 3662 \\
\hline \multirow{2}{*}{ Belonging to a minority ethnic background } & No & 94.55 & 8664 \\
\hline & Yes & 5.45 & 499 \\
\hline \multirow{2}{*}{ Living with a husband/wife/partner } & No & 42.13 & 3860 \\
\hline & Yes & 57.87 & 5303 \\
\hline \multirow{2}{*}{$\begin{array}{l}\text { Participation in work-related training in the } \\
\text { previous } 12 \text { months }\end{array}$} & No & 39.54 & 3623 \\
\hline & Yes & 60.46 & 5540 \\
\hline \multicolumn{4}{|c|}{ Independent variables at country-level } \\
\hline GDP per capita PPS & $105 *$ & & \\
\hline \multirow{2}{*}{ Full democracy } & No & 45.83 & 11 \\
\hline & Yes & 54.17 & 13 \\
\hline
\end{tabular}

Abbreviation: GDP per capita in PPS = Gross domestic product (GDP) in Purchasing Power Standards (PPS)

* Age and GDP per capita PPS are continuous variables. This is why here we present the means.

\section{Notes}

Indeed, there is a discussion within the capability approach about the question of a list of central capabilities which reflects two different accounts. Sen does not design such a list. Instead, he claims that the correctness of the rankings when assessing the comparative merits of capabilities or primary goods can be assumed via broad agreement based on public reasoning. Nussbaum endorses a universal list of 10 central human capabilities. This list is oriented to the threshold of capabilities that should be provided for each human being in relation to their dignity. 


\section{References}

Allen, Jim, and Rolf van der Velden. 2001. Educational mismatches versus skill mismatches: Effects on wages, job satisfaction, and on-the-job search. Oxford Economic Papers 53: 434-52. [CrossRef]

Allen, Jim, and Rolf van der Velden, eds. 2011. The Flexible Professional in the Knowledge Society: New Challenges for Higher Education. Dordrecht: Springer.

Becker, Gary. 1993. Human Capital: A Theoretical and Empirical Analysis with Special Reference to Education, 3rd ed. London: The University of Chicago Press. First published 1964.

Bergström, Gunilla. 2012. Capabilities for education, work and voice from the perspective of "the less employable" university graduates. Social Work \& Society 10: 1-15.

Boeren, Ellen. 2021. Are adult learners in Europe happier than non-learners? Statistical evidence from the European Social Survey. European Educational Research Journal. [CrossRef]

Boyadjieva, Pepka, and Petya Ilieva-Trichkova. 2016. Rethinking missions and values of higher education: Insights from the capability approach and the institutional perspective. In Positioning Higher Education Institutions: From Here to There. Edited by Rosalind M. O. Pritchard, Attila Pausits and James Williams. Rotterdam: Sense, pp. 41-62.

Capsada-Munsech, Queralt. 2019. Measuring overeducation: Incidence, correlation and overlaps across indicators and countries. Social Indicators Research 145: 279-301. [CrossRef]

Cedefop. 2019. Skills Panorama. Available online: https://skillspanorama.cedefop.europa.eu/en/dashboard/over-qualification-ratetertiary-graduates? year=2019\&country=EU\#1 (accessed on 1 March 2021).

Chevalier, Arnaud, and Joanne Lindley. 2009. Overeducation and the skills of UK graduates. Journal of the Royal Statistical Society. Series A Statistics in Society 172: 307-37. [CrossRef]

Collins, Randall. 1979. The Credential Society: A Historical Sociology of Education and Stratification. First Printing Edition. New York: Academic Press.

Congregado, Emilio, Jesús Iglesias, José María Millán, and Concepción Román. 2016. Incidence, effects, dynamics and routes out of overqualification in Europe: A comprehensive analysis distinguishing by employment status. Applied Economics 48: 411-45. [CrossRef]

Deeming, Chris, and David Hayes. 2012. Worlds of welfare capitalism and wellbeing: A multilevel analysis. Journal of Social Policy 41: 811-29. [CrossRef]

Delaney, Judith, Seamus McGuinness, Konstantinos Poulakis, and Paul Redmond. 2020. Educational expansion and overeducation of young graduates: A comparative analysis of 30 European countries. Oxford Review of Education 46: 10-29. [CrossRef]

Diem, Andrea. 2015. Overeducation among graduates from universities of applied sciences: Determinants and consequences. Journal of Economic and Financial Studies 3: 63-77. [CrossRef]

Drèze, Jean, and Amartya Sen. 2002. India: Development and Participation. Oxford: Oxford University Press.

ESS Round 6: European Social Survey Round 6 Data. 2012. Data File Edition 2.4. NSD—Norwegian Centre for Research Data, Norway-Data Archive and distributor of ESS data for ESS ERIC. [CrossRef]

European Commission. 2012. EU Youth Report. Luxembourg: Office for Official Publications of the European Communities.

European Social Survey. 2013. Round 6 Module on Personal and Social Wellbeing-Final Module in Template. London: Centre for Comparative Social Surveys, City University London.

Fleming, Christopher M., and Parvinder Kler. 2014. Female overeducation, job satisfaction and the impact of children at home in Australia. Economic Analysis and Policy 44: 143-55. [CrossRef]

Frank, Kristyn, and Feng Hou. 2017. Over-education and well-being: How does education-occupation mismatch affect the life satisfaction of university-educated immigrant and non-immigrant workers? Ethnicity $\mathcal{E}$ Health 23: 884-901.

Green, Francis, and Yu Zhu. 2010. Overqualification, job dissatisfaction, and increasing dispersion in the returns to graduate education. Oxford Economic Papers 62: 740-63. [CrossRef]

Hinchliffe, Geoffrey. 2013. Employability: A capability approach. In Human Development and Capabilities: Re-Imagining the University of the Twenty-First Century. Edited by Alejandra Boni and Melanie Walker. London and New York: Routledge, pp. 82-96.

Hirsch, Fred. 1976. Social Limits to Growth. Cambridge: Harvard University Press.

Honneth, Axel. 1992. Integrity and disrespect: Principles of a conception of morality based on a theory of recognition. Political Theory 20: 187-201. [CrossRef]

Ilieva-Trichkova, Petya, and Pepka Boyadjieva. 2016. Expansion of higher education and graduate employability: Data and insights from Central and Eastern Europe. In Labour and Social Transformations in Central and Eastern Europe: Europeanization and Beyond. Edited by Violaine Delteil and Vassil Kirov. New York: Routledge, pp. 207-27.

Ilieva-Trichkova, Petya, and Pepka Boyadjieva. 2017. Higher education as a heterogeneous good: Vertical education-job mismatch among graduates. Sociological Problems 49: 80-100.

ILO. 2014. Skills Mismatch in Europe: Statistics Brief. Geneva: International Labour Office, Department of Statistics.

Mavromaras, Kostas, Stéphane Mahuteau, Peter Sloane, and Zhang Wei. 2012. The Effect of Overskilling Dynamics on Wages. IZA Discussion Paper No. 6985. Available online: unimelb.edu.au (accessed on 24 April 2021).

McGuinness, Seamus. 2006. Overeducation in the labour market. Journal of Economic Surveys 20: 387-418. [CrossRef]

McGuinness, Seamus, and Delma Byrne. 2015. Born abroad and educated here: Examining the impacts of education and skill mismatch among immigrant graduates in Europe. IZA Journal of Migration 4: 1-30. [CrossRef] 
McGuinness, Seamus, and Peter J. Sloane. 2011. Labour market mismatch among UK graduates: An analysis using REFLEX data. Economics of Education Review 30: 130-45. [CrossRef]

McGuinness, Seamus, Konstantinos Pouliakas, and Paul Redmond. 2018. Skills mismatch: Concepts, measurement and policy approaches. Journal of Economic Surveys 32: 985-1015. [CrossRef]

Mincer, Jacob. 1958. Investment in human capital and personal income. Journal of Political Economy 66: 281-302. [CrossRef]

Nussbaum, Marta. 2000. Women and Human Development. Cambridge: Cambridge University Press.

Nussbaum, Marta. 2003. Capabilities as fundamental entitlements: Sen and social justice. Feminist Economics 9: 33-59. [CrossRef]

Nussbaum, Marta. 2011. Creating Capabilities. The Human Development Approach. Cambridge and London: The Belknap Press of Harvard University Press.

Nussbaum, Marta, and Amartya Sen. 1993. Introduction. In The Quality of Life. Edited by Marta Nussbaum and Amartya Sen. Oxford: Clarendon Press, pp. 8-14.

Peiró, José M., Sonia Agut, and Rosa Grau. 2010. The relationship between overeducation and job satisfaction among young Spanish workers: The role of salary, contract of employment, and work experience. Journal of Applied Social Psychology 40: 666-89. [CrossRef]

Piper, Alan. T. 2015. Heaven knows I'm miserable now: Overeducation and reduced life satisfaction. Education Economics 23: 677-92. [CrossRef]

Quintini, Glenda. 2011. Over-Qualified or Under-Skilled: A Review of Existing Literature. OECD Social, Employment and Migration Working Papers No. 121. Paris: OECD Publishing. Available online: https://doi.org/10.1787/5kg58j9d7b6d-en (accessed on 24 April 2021).

Rabe-Hesketh, Sophia, and Anders Skrondal. 2012. Multilevel and Longitudinal Modeling Using Stata, 3rd ed. College Station: Stata Press, vols. 1 and 2.

Robeyns, Ingrid. 2003. Sen's capability approach and gender inequality: Selecting relevant capabilities. Feminist Economics 9: 61-92. [CrossRef]

Robeyns, Ingrid. 2006. Tree models of education: Rights, capabilities and human capital. Theory and Research in Education 4: 69-84. [CrossRef]

Robeyns, Ingrid. 2017. Wellbeing, Freedom and Social Justice. The Capability Approach Re-Examined. Cambridge: Open Book Publishers.

Schofer, Evan, and John W. Meyer. 2005. The worldwide expansion of higher education in the twentieth century. American Sociological Review 70: 898-920. [CrossRef]

Schultz, Theodore. W. 1961. Investment in human capital. The American Economic Review 51: 1-17.

Schyns, Peggy. 1998. Crossnational differences in happiness: Economic and cultural factors explored. Social Indicators Research 43: 3-26. [CrossRef]

Sen, Amartya. 1985. Well-being, agency and freedom: The Dewey lectures 1984. The Journal of Philosophy 82: 169-221. [CrossRef]

Sen, Amartya. 1992. Inequality Reexamined. Oxford: Oxford University Press.

Sen, Amartya. 1997. Editorial: Human capital and human capability. World Development 25: 1959-61. [CrossRef]

Sen, Amartya. 1999. Development as Freedom. Oxford: Oxford University Press.

Sen, Amartya. 2009. The Idea of Justice. Cambridge: The Belknap Press of Harvard University Press.

Sloane, Peter J., and Kostas Mavromaras. 2020. Overeducation, Skill Mismatches, and Labor Market Outcomes for College Graduates. Available online: iza.org (accessed on 6 July 2021).

Stiglitz, Joseph E., Amartya Sen, and Jean-Paul Fitoussi. 2010. Mismeasuring Our Lives. Why GDP Doesn't Add Up? The Report by the Commission on the Measurement of Economic Performance and Social Progress. New York and London: The New Press.

Støren, Liv Anne, and Clara Åse Arnesen. 2011. Winners and losers. In The Flexible Professional in the Knowledge Society. Edited by Jim Allen and Rolf van der Velden. Dordrecht: Springer, pp. 199-240.

Suppa, Nicolai. 2015. Capability deprivation and life satisfaction. Evidence from German panel data. Journal of Human Development and Capabilities 16: 173-99. [CrossRef]

Taylor, Charles. 1992. Multiculturalism and 'The Politics of Recognition'. Edited by Amy Gutmann. Princeton: Princeton University Press.

The Economist Intelligence Unit. 2012. Democracy Index 2012. Democracy at a Standstill. A Report from The Economist Intelligence Unit. Available online: eiu.com (accessed on 24 April 2021).

Tholen, Gerbrand. 2015. What can research into graduate employability tell us about agency structure? British Journal of Sociology of Education 36: 766-84. [CrossRef]

Thurow, Lester. 1975. Generating Inequality. New York: Basic Books.

Verhaest, Dieter, and Eddy Omey. 2006. Discriminating between alternative measures of over-education. Applied Economics 38: 2113-20. [CrossRef]

Verhaest, Dieter, and Rolf van der Velden. 2013. Cross-country differences in graduate overeducation. European Sociological Review 29: 642-53. [CrossRef]

Voces, Carmen, and Miguel Caínzos. 2020. Overeducation as status inconsistency: Effects on job satisfaction, subjective well-being and the image of social stratification. Social Indicators Research 153: 979-1010. [CrossRef]

Walker, Melanie, and Samuel Fongwa. 2017. Universities, Employability and Human Development. London: Palgrave Macmillan. 